\title{
Factors associated with the choice of a second specialty among internal medicine residency graduates
}

\author{
Fatores associados à escolha da segunda especialidade entre concluintes da residência em clínica médica
}

\author{
Marco Felipe Macêdo Alves ${ }^{1}$ (1) marcofma7@gmail.com \\ Jardelina Brena Rocha Leite1 (1) brenaarochaa17@gmail.com \\ Norma Arteiro Filgueira' (D) norma.arteiro@hotmail.com
}

\begin{abstract}
Introduction: After the residency in Internal Medicine, most graduates choose to undergo a new selection process to obtain a second specialty. The phenomenon of early specialization is encouraged as early as in the undergraduate course. Despite this, the demand for general practitioners is growing.

Objective: To investigate the factors that lead the newly graduated clinician to undertake a new residency.

Method: This is a cross-sectional study that analyzes the responses of Internal Medicine residency graduates from the state of Pernambuco in 2020, through a questionnaire available online by Google Forms, containing questions about social aspects, undergraduate medical course, Medical Residency and intentions for the future career.

Results: There were 81 responses of the 104 possible participants (77.88\%). Most of these were female (66.67\%), graduated from public universities (69.14\%) and had already started the Internal Medicine residency shortly after graduation (50.62\%). Regarding the specialty choice, 51.85\% answered they had decided in the second year of residency, and $80.25 \%$ stated that they had undergone the selection process for the second specialty shortly after completing the Internal Medicine residency. The most often chosen career was Cardiology (20\%). The factors most often associated with the choice of specialty were, according to the means on the Likert scale, "work in an outpatient setting", "long-term patient followup", and "more contact with patients".
\end{abstract}

Conclusion: As far as it could be investigated in the literature, this was the first Brazilian study on specialty choices after the Internal Medicine residency. It was possible to identify the most important reasons for choosing a second specialty among the graduates of this Medical Residency program in Pernambuco in 2020. More studies are needed to establish correlations between the factors of choice with the chosen specialty.

Keywords: Medical Residency; Internal Medicine; Medical Specialties; Medical Education; Career Choice.

\section{RESUMO}

Introdução: Após a residência em clínica médica, a maioria dos concluintes opta por se submeter a um novo processo seletivo para obter uma segunda especialidade. O fenômeno da especialização precoce é incentivado já na graduação. Apesar disso, a demanda por médicos generalistas está em crescimento.

Objetivo: Este estudo teve como objetivo investigar os fatores que levam o clínico recém-formado a realizar uma nova residência.

Método: Trata-se de um estudo transversal que analisou as respostas dos concluintes do Programa de Residência Médica em Clínica Médica (PRM-CM) realizado em 2020 no estado de Pernambuco. Os concluintes do PRM-CM, por meio de um questionário disponibilizado de forma on-line pelo Google Forms, responderam a perguntas sobre aspectos sociais, a graduação, a residência médica e intenções para a carreira futura.

Resultado: Dos 104 participantes possíveis, houve 81 respostas (77,88\%). Desse total final, 66,67\% eram do sexo feminino, 69,14\% tinham se graduado em universidades públicas, e 50,62\% já haviam iniciado o PRM-CM logo após a graduação. Quanto à escolha de especialidade, 51,85\% responderam ter decidido no segundo ano de residência, e 80,25\% afirmaram ter se submetido ao processo seletivo para a segunda especialidade logo após o PRM-CM. A carreira mais escolhida foi cardiologia (20\%). Os fatores mais associados à escolha de especialidade foram, de acordo com as médias na escala de Likert, "trabalho em ambiente ambulatorial", "acompanhamento de pacientes por longo período" e "mais contato com pacientes".

Conclusão: Até onde se pôde investigar na literatura, este é o primeiro estudo brasileiro a abordar as escolhas de especialidade após o PRM-CM. Foi possível identificar os motivos mais importantes para escolher uma segunda especialidade entre os concluintes desse PRM em Pernambuco, em 2020. Mais estudos são necessários para tecer correlações entre os fatores de escolha com a especialidade escolhida.

Palavras-chave: Residência Médica; Medicina Interna; Especialidades Médicas; Educação Médica; Escolha da Profissão.

${ }^{1}$ Universidade Federal de Pernambuco, Recife, Pernambuco, Brazil.

Chief Editor: Rosiane Viana Zuza Diniz.

Associate Editor: Jorge Carvalho Guedes.

Received on 07/26/21; Accepted on 09/08/21.

Evaluated by double blind review process. 


\section{INTRODUCTION}

Internal Medicine is the medical specialty that deals with the adult health-disease process, also working in health promotion and disease prevention, in an outpatient, home or hospital setting. Most clinical specialties are derived from it ${ }^{1}$. Therefore, training in Internal Medicine is a prerequisite for admission to residencies in Allergy and Immunology, Angiology, Clinical Cancerology, Cardiology, Endocrinology, Gastroenterology, Geriatrics, Hepatology, Hematology and Hemotherapy, Nephrology, Pulmonology, and Rheumatology, and may also be a mandatory prerequisite for Endoscopy, Nutrology and Intensive Care ${ }^{2}$.

The choice of medical specialty usually begins in the first semesters of undergraduate school and may change throughout the course and professional career. Previous studies have shown that it depends on multiple variables, such as financial return, possibility of division between work and free time, broader or more specific knowledge, influence of medical relatives and/or professors and affinity with the specialty ${ }^{3}$.

Some studies in the international literature have discussed the reasons for the clinician to choose to subspecialize. Based on these, it is possible to state that there is an increasing trend among these professionals to undertake a second specialization ${ }^{4-5}$, standing out as important factors a more controllable lifestyle and experiences in the residency period $^{6}$, as well as the intention of monitoring patients in the long term and greater financial return ${ }^{4,7}$.

In the Brazilian literature, moreover, there are no studies directly related to decisions after Internal Medicine residency. Nevertheless, there are studies that address the undergraduate medical course, which show that the traditional teaching model in Medical Schools seems to encourage early specialization, either because the knowledge is fragmented into specialties, or because the care of the individual's health is greater than the collective health, or due to the creation of the image that more complex specialties bring more social prestige and greater financial return ${ }^{8}$.

Considering the abovementioned impasses, this study will investigate the factors that lead to the choice of a second specialty among Medical Residency graduates in Internal Medicine in the state of Pernambuco, Brazil. Moreover, the study will profile the Internal Medicine residency graduate in the state of Pernambuco in 2020 and will determine the frequency of choice for a second Medical Residency Program (MRP) after finishing the Internal Medicine residency and will analyze the reasons for not undergoing a second selection process in the current year.

\section{METHOD}

This is an analytical, observational, quantitative, crosssectional study, built from a questionnaire that was applied electronically through the Internet, available on the Google Forms platform, to graduates from the Medical Residency Program (MRP) in Internal Medicine in the state of Pernambuco in February 2020.

The questionnaire contains the following sets of questions:

- General Information (gender, place and year of medical course completion, public or private university, with whom they resided during the Medical Residency, previous work and children);

- Information about the MRP in Internal Medicine concluded in February 2020 (Location, whether or not in their city of origin, whether or not the service has an emergency department);

- Information about the next Medical Residency (whether there was a selection process for Medical Residency for the year 2020, to which program[s] they applied, motivations for choosing the second specialty, moment of choice). The Likert scale model was used for the factors that motivated the choice of the medical residency, with five response options for each item - I strongly disagree (1), I partially disagree (2), I neither agree nor disagree (3), I partially agree (4) and I strongly agree (5) - for the volunteer to select the one most adequate to their profile.

- Reasons for not undergoing a second selection process at the end of the MRP in Internal Medicine.

The nominal list of graduates was sent by the Pernambuco State Medical Residency Commission (CEREM$\mathrm{PE})$, containing 105 graduates from the $2020 \mathrm{MRP}$ in Internal Medicine. Among these, one participant was excluded, as the completion of the residency was postponed to August, due to maternity leave. Therefore, 104 graduates remained, who were sent the link to the survey through WhatsApp Messenger.

They were allowed to send the answers up to January 5, 2021. The Free and Informed Consent form was also signed online, before they had access to the survey form.

\section{Inclusion and Exclusion Criteria}

- Inclusion criteria - Having completed the Medical Residency Program in Internal Medicine in the state of Pernambuco in February/2020.

- Exclusion criteria - Delay in the completion of the Internal Medicine Medical Residency Program, due 
to leave of absence, maternity or sick leave or any other reasons not listed herein.

\section{Statistical analysis}

Data were grouped as measures of central tendency and proportions. For the analysis of factors associated with the choice of specialty, the Likert scale responses were grouped as follows:

- "I neither agree, nor disagree", "I partially disagree" and "I strongly disagree" were grouped as no influence on the choice

- "I strongly agree" and "I partially agree" were grouped as having influenced the choice.

The answers were transformed into Microsoft Excel spreadsheets and analyzed using the R program for Windows, version 3.2.2 - 2015 - R Foundation for Statistical Computing.

\section{Ethical aspects}

The research complies with the ethical precepts of Resolution 466/12 of the National Health Council, involving electronic approval of the Free and Informed Consent form (FICF) for its performance. The volunteers' anonymity was guaranteed through the confidentiality of the research data, as access to the data was restricted to the participating researchers through a virtual password, and because the participants did not need to inform their names in the research form. There was no direct benefit to the volunteers; however, the data collected will contribute to strategic planning actions for the Medical Residency programs in Internal Medicine.

The research project was approved by the Pernambuco State Medical Residency Commission (CEREM-PE) and approved by the Research Ethics Committee of Hospital das Clínicas, Universidade Federal de Pernambuco (HC-UFPE) (CAAE: 39795920.0.0000.8807).

\section{RESULTS}

Of the 104 possible participants, 88 responses were obtained, of which 7 were excluded because they were duplicates. Thus, 81 valid responses remained, which corresponds to $77.88 \%$ of the respondents. Table 1 shows the valid responses by service in which the Internal Medicine MRP was carried out. Residents from all services in which the Internal Medicine MRP was completed in the state of Pernambuco in 2020 participated in the study.

Table 1 shows the answers related to the social characteristics and variables about undergraduate school and residency. Most participants were female (66.67\%), did not have children (91.36\%) and graduated from public universities (69.14\%).
Most of the volunteers (74.07\%) had graduated from universities in the state of Pernambuco, most at the Universidade de Pernambuco (UPE) - 28.04\%. Furthermore, 50.62\% followed the course of early specialization - they entered the MRP in Internal Medicine right after graduation.

Finally, the respondents who reported having worked in family health and/or basic emergency units before the MRP in Internal Medicine predominated. Additionally, it seems that, during the residency, there was a significant number of volunteers who lived with a spouse/partner, parents or friends.

Table 2 shows the factors related to the choice of a second residency by the Internal Medicine MRP graduates in the state of Pernambuco. It was observed that most graduates chose the specialty during the second year of residency and that $80.25 \%$ chose to take the test for a new specialty, with $7.41 \%$ taking the test for more than one specialty. Moreover, among the specialty options, the five most frequently chosen were, in decreasing order: Cardiology (20.0\%), Endocrinology (15.56\%), Nephrology (11.11\%), Geriatrics (11.11\%) and Pulmonology (7.78\%).

Table 1. Characteristics of 81 graduates of the 2020 Pernambuco MRP in Internal Medicine.

\begin{tabular}{lcc}
\hline \multicolumn{1}{c}{ Characteristic } & N & Frequency \\
\hline Female gender & 54 & $66.67 \%$ \\
Have children & 7 & $8.64 \%$ \\
Graduated from public university & 56 & $69.14 \%$ \\
$\begin{array}{l}\text { Graduated from universities located in } \\
\text { Pernambuco }\end{array}$ & 60 & $74.07 \%$ \\
Started Residency in the first year after & 41 & $50.62 \%$ \\
graduation & & \\
\multicolumn{1}{c}{ Worked prior to residency } & 56 & $69.14 \%$ \\
Basic Emergency Unit & 42 & $51.85 \%$ \\
Family Health Unit (Primary Care) & 32 & $39.51 \%$ \\
Emergency Reference & 19 & $23.46 \%$ \\
Intensive care unit $_{\text {Evolutionary Medicine }}$ & 7 & $8.64 \%$ \\
Others & & \\
\hline
\end{tabular}

\section{With whom did you live during the Residency?}

$\begin{array}{lcc}\text { Partner/Spouse } & 25 & 30.87 \% \\ \text { Parents } & 23 & 28.40 \% \\ \text { By myself } & 20 & 24.69 \% \\ \text { Other relative(s) } & 12 & 14.81 \% \\ \text { Friends } & 1 & 1.23 \%\end{array}$

a. Others: Home (6.17\%), Armed Forces (3.7\%), Private practice (2.47\%), Dialysis Clinic (1.23\%). 
Table 2. Factors related to the choice of the second specialty among graduates of the Internal Medicine Medical Residency Program in the state of Pernambuco.

\begin{tabular}{|c|c|c|}
\hline Moment when they chose the Specialty & $\mathbf{N}$ & Frequency \\
\hline Graduation & 31 & $38.27 \%$ \\
\hline Between graduation and residency & 4 & $4.94 \%$ \\
\hline Second year of residency & 42 & $51.85 \%$ \\
\hline Took the test for a second residency & 65 & $80.25 \%$ \\
\hline \multicolumn{3}{|l|}{ For which specialty did you take the test? ${ }^{a}$} \\
\hline Cardiology & 18 & $20.0 \%$ \\
\hline Endocrinology & 14 & $15.56 \%$ \\
\hline Geriatrics & 10 & $11.11 \%$ \\
\hline Oncology & 4 & $4.44 \%$ \\
\hline Palliative care & 4 & $4.44 \%$ \\
\hline Others $^{\mathrm{b}}$ & 15 & $16.67 \%$ \\
\hline $\begin{array}{l}\text { Would you have taken the Internal Medicine Residency even if it was not a } \\
\text { mandatory prerequisite? }\end{array}$ & 49 & $60.49 \%$ \\
\hline Total & 81 & $100 \%$ \\
\hline
\end{tabular}

a. For this item, consider a total of 90, due to participants with two or three answers.

b. Others: Specialties that received between 1 and 3 votes, in decreasing order: Rheumatology, Additional Year in Internal Medicine, Psychiatry, Intensive Care Medicine, Infectious Diseases, Endoscopy, Nutrology, Hepatology and Hematology/Hemotherapy.

Table 3. Factors associated with the choice of specialty after residency in Internal Medicine.

\begin{tabular}{|c|c|c|c|}
\hline Factor & Mean & $\mathrm{Cl}(95 \%)$ & Influence \\
\hline Working in an outpatient environment & 4.16 & $3.91-4.41$ & $79.75 \%$ \\
\hline Long-term patient follow-up & 4.08 & $3.83-4.33$ & $72.15 \%$ \\
\hline Positive experiences in residency & 3.82 & $3.56-4.08$ & $68.35 \%$ \\
\hline Wide Field of Work & 3.75 & $3.46-4.04$ & $58.23 \%$ \\
\hline Better planning of work routine & 3.67 & $3.43-3.91$ & $58.97 \%$ \\
\hline Contact with academic/university environment & 3.59 & $3.32-3.86$ & $56.96 \%$ \\
\hline Positive undergraduate experiences & 3.57 & $3.25-3.89$ & $60.76 \%$ \\
\hline Work in a hospital environment & 3.56 & $3.29-3.83$ & $56.96 \%$ \\
\hline Influence of teachers during undergraduate school & 2.99 & $2.69-3.29$ & $34.18 \%$ \\
\hline Possibility of performing procedures & 2.76 & $2.42-3.10$ & $37.97 \%$ \\
\hline Influence of preceptors during residency & 2.70 & $2.39-3.01$ & $30.38 \%$ \\
\hline Most of the time working alone & 2.22 & $1.96-2.48$ & $11.39 \%$ \\
\hline Less contact with end-of-life patients & 1.89 & $1.63-2.15$ & $10.13 \%$ \\
\hline Less competition in the test & 1.58 & $1.37-1.80$ & $5.06 \%$ \\
\hline
\end{tabular}


Table 3 shows, in decreasing order of the means on the Likert Scale, the most important factors for choosing the second specialty after completing the MRP in Internal Medicine, and their respective confidence intervals, in addition to the percentage of responses transformed into "positive influence", that is, those with scores of 4 or 5 on the Likert scale, representing, respectively, partially agree or strongly agree.

Moreover, 16 volunteers (19.75\%) did not take the test for a second selection process in 2020 . Of these, two reported having no intention of taking the test in the future, one of which justified by saying their vocation is internal medicine, while the other did not justify it. Among the 14 who reported their intention to undergo a new selection process in the future, the reasons for not doing it at the moment were as follows (Table 4).

\section{DISCUSSION}

As far as it has been possible to investigate in the literature, this is the first Brazilian study to analyze the reasons for deciding on a second specialty after completing the residency in Internal Medicine, in addition to investigating the epidemiological profile of residents and the reasons for not undergoing a new selection process at the moment.

Thus, we observed that the main determining factors for choosing the second specialty were: 1) Work in an outpatient environment; 2) Follow-up of patients for long periods; 3) More contact with patients.

Clinicians must have, among their competences, the ability to work both in the hospital and the outpatient environment ${ }^{9}$. The current hospital-centric model of Medical Residency, despite providing training in the hospital care model in shifts and in-patient evolution, may weaken the training in the outpatient setting. More recently, there has been a growing trend to increase the workload in outpatient clinics and to promote the hospital-outpatient relationship to improve clinician education ${ }^{10}$. This need can be corroborated by the finding in our study that the main determining factor for choosing the second specialty was working in an outpatient setting, which is one of the main fields of work in most clinical specialties. Therefore, better medical office training can provide better clinicians and better specialists to society.

Moreover, it is observed that the two other factors considered more important for the decision on the second specialty-long-term monitoring and contact with patients - are probably common to Internal Medicine and clinical specialties. In the Brazilian Medical Demography study ${ }^{11}$, it is demonstrated that $90.9 \%$ of the physicians participating in the research work in direct contact with patients. This can highlight the need for training in the physician-patient relationship, empathy and communication during the Internal Medicine Residency, which,
Table 4. Reasons for not undergoing a new selection process at that time.

\begin{tabular}{lcc}
\hline \multicolumn{1}{c}{ Reason } & Answers & Frequency \\
\hline Tired after the residency period & 11 & $78.57 \%$ \\
Undecided about which specialty to & 7 & $50 \%$ \\
follow & 5 & $35.71 \%$ \\
Financial conditions & 4 & $28.57 \%$ \\
Staying close to family members & 2 & $14.29 \%$ \\
Caring for their children & 14 & $100 \%$ \\
\hline Total & & \\
\hline
\end{tabular}

as well as outpatient care, are competences explained in the latest Competence Matrices in Internal Medicine9.

For comparison purposes, a study carried out in 2005 in the United States showed that the main factors that led Internal Medicine residents to undertake a subspecialty were long-term relationships with patients, a more specific field of practice and caring for critically ill patients ${ }^{12}$.

In our study, of the 81 participants, 65 reported having taken the test for clinical specialty (80.25\%) and another 14 reported having the intention to do it in the future $(17.28 \%)$; therefore, $97.53 \%$ of the participants had the intention to work in subspecialties. This number is higher than that found in a study carried out in the United States, which showed that $64.2 \%$ of residents in the third year of Internal Medicine intended to work in subspecialties ${ }^{4}$. Additionally, another study carried out in the United States showed that $59 \%$ of the graduates had plans to undertake a second specialty ${ }^{5}$. Therefore, the results found in our study agrees with those of other studies, showing that most Internal Medicine Residency graduates tend to pursue a second specialty. Nevertheless, our study found that most participants would have taken on this residency even if it were not a mandatory prerequisite for the residency in the second specialty, demonstrating the recognition of the importance of Internal Medicine as the basis for working in the specialties.

Regarding the epidemiological profile of the Internal Medicine MRP graduates in the state of Pernambuco in 2020 , there is a majority of women (66.67\%), confirming the increasing female participation in recent years in the medical area in Brazil ${ }^{11}$.

Additionally, most of the Internal Medicine graduates declared to have graduated from public universities, in contrast with data from the Medical Demography 2020 study, in which the majority of participating physicians declared to have graduated from private universities ${ }^{11}$. There are two factors that can explain this disparity: first, the literature shows better results in the National Student Performance Test (ENADE, Exame Nacional de Desempenho dos Estudantes) 
among medical students from public universities ${ }^{13}$, which may explain a better performance in the selection processes for Medical Residency; moreover, there has been an increase in the offer of student funding in Brazilian private medical schools ${ }^{14}$ in the last decade, and evidence points to a greater tendency to pursue a career as a general practitioner among those with greater debts related to education?.

Moreover, most participants reported having undergone the selection process for admission to Internal Medicine Residency soon after graduation, which shows the tendency of early specialization of Brazilian physicians ${ }^{15}$, which sometimes occurs due to personal or social pressure ${ }^{3}$. Another factor found in the present study is that the minority of the participants has children, which may corroborate the young age at which medical specialization has been taking place. The decisive choice of specialty in our study occurred, most of the time, in the second year of residency, which agrees with other studies ${ }^{5}$; however, a significant number of participants reported having chosen their specialty during undergraduate medical school.

Another aspect that deserves to be highlighted is that $80.25 \%$ of the participants have already undergone a new selection process for a second specialty right after the end of the Internal Medicine residency, also showing early subspecialization. This can occur due to several factors, including: 1) the lack of appreciation of the clinician by society and by the labor market, often not making distinctions between the clinician and the General Practitioner ${ }^{16}$; 2) the growing medical intention to have a more restricted area of knowledge ${ }^{11}$, either for fear of not being able to keep up to date with an increasing rapidly changing science, or for not wanting to provide holistic care (which requires time and dedication in each consultation, reducing the number of patients seen per shift). In a world where medicine is becoming increasingly fragmented, there is a growing repressed demand for the clinicians, as they are the professionals who manage to solve most problems - before consulting a subspecialist and who manage to reconcile the several prescriptions and guidelines given to patients with multimorbidities in different work environments ${ }^{17}$.

As for the reasons for not undergoing a selection process for a second specialty at the time, the main answer was "because they were tired due to the residency period", which agrees with other studies that depicted the number of residents who experience Burnout Syndrome during graduate studies ${ }^{18-20}$, which may negatively influence both the choice and the time to undertake a new medical residency.

As limitations of our study, one must mention first the small sample size, which made it difficult to analyze the factors that determine the choices of each specialty. Moreover, it was not possible to perform the analysis on associations between the different variables, which may have been due to the study design, requiring larger studies for more robust analyses.

\section{CONCLUSION}

In this study, the most important factors for choosing the second specialty after the Internal Medicine residency were: working in an outpatient setting, long-term followup of patients, and more contact with patients. More studies are needed to establish correlations between the factors of choice and the chosen specialty, aiming to better understand the processes that lead to the decision to undertake a second specialty after Internal Medicine.

\section{AUTHORS' CONTRIBUTION}

Marco Felipe Macêdo Alves and Norma Arteiro Filgueira: Contributed to the manuscript writing, the research project, data collection, formatting of the data and the bibliographical review. Jardelina Brena Rocha Leite: Contributed to the manuscript writing and review and data collection.

\section{CONFLICTS OF INTEREST}

The authors declare no conflicts of interest.

\section{SOURCES OF FUNDING}

The authors declare no sources of funding.

\section{REFERENCES}

1. Conselho Regional de Medicina de São Paulo. Parecer: Consulta n 60.960 Brasília: Cremesp; 2010 [access in 28 jun 2020]. Available from: http://www. cremesp.org.br $/$ ?siteAcao $=$ Pareceres, $\mathrm{dif}=\mathrm{s}, \mathrm{ficha}=1, \mathrm{id}=9701, \mathrm{tipo}=\mathrm{PARE}$ CER,orgao=Conselho\%2520Regional\%2520de\%2520Medicina\%2520do \%2520Estado\%2520de\%2520S\%25E3o\%2520Paulo,numero=60960,situacao $=$,data $=23-11-2010$ Brazilian Portuguese.

2. Comissão Nacional de Residência Médica. Resolução CNRM n 02/2006 Dispõe sobre requisitos mínimos dos Programas de Residência Médica e dá outras providências. Brasília: CNRM; 2006 [access in 28 jun 2020]. Available from: http://portal.mec.gov.br/dmdocuments/resolucao02_2006.pdf.

3. Martins JB, Rodriguez FP, Coelho ICMM, Silva EM. Fatores que influenciam a escolha da especialização médica pelos estudantes de Medicina em uma instituição de ensino de Curitiba (PR). Rev Bras Educ Med. 2019;43(2):152 8. doi: 10.1590/1981-52712015v43n2rb20180158.

4. West $\mathrm{CP}$, Dupras DM. General medicine vs subspecialty career plans among internal medicine residents. JAMA. 2012;308(21):2241-7. doi 10.1001/jama.2012.47535.

5. Yang J, Singhal S, Weng Y, Bentley JP, Chari N, Liu T, et al. Timing and predictors of subspecialty career choice among internal medicine residents: a retrospective cohort study. J Grad Med Educ. 2020 Apr 10;12(2):212-6. doi: 10.4300/JGME-D-19-00556.1.

6. Horn L, Tzanetos K, Thorpe K, Straus SE. Factors associated with the subspecialty choices of internal medicine residents in Canada. BMC Med Educ. 2008;8(1):1-8. doi: 10.1186/1472-6920-8-37.

7. Diehl AK, Kumar V, Gateley A, Appleby JL, O'Keefe ME. Predictors of final specialty choice by internal medicine residents. J Gen Intern Med. 2006;21(10):1045-9. doi: 10.1111\%2Fj.1525-1497.2006.00556.x. 
8. Costa JRB, Romano VF, Costa RR, Gomes AP, Alves LA, Siqueira-Batista R. A transformação curricular e a escolha da especialidade médica. Rev Bras Educ Med. 2014;38(1):47-58. doi:10.1590/\$0100-55022014000100007.

9. Ministério da Educação. Matrizes de Competências em Clínica Médica. Brasília; MEC; 2018 [access in 11 feb 2021]. Available from: http://portal. mec.gov.br/index.php?option=com_docman\&view=download\&ali as=119741-13-matriz-de-competencias-em-clinica-medica\&category slug=agosto-2019-pdf\&ltemid=30192.

10. Armstrong K, Keating NL, Landry M, Crotty BH, Phillips RS, Selker HP. Academic general internal medicine: a mission for the future. J Gen Intern Med. 2013;28(6):845-51. doi: 10.1007/s11606-013-2334-3.

11. Scheffer M, Cassenote A, Guerra A, Guilloux AGA, Brandão APD, Miotto BA, et al. Demografia médica no Brasil 2020. São Paulo: FMUSP, CFM; 2020 [access in 08 feb 2021]. Available from: https://www.fm.usp.br/fmusp/ conteudo/DemografiaMedica2020_9DEZ.pdf.

12. Garibaldi RA, Popkave C, Bylsma W. Career plans for trainees in internal medicine residency programs. Acad Med. 2005;80(5):507-12. doi: 10.1097/00001888-200505000-00021.

13. Scheffer MC, Dal Poz MR. The privatization of medical education in Brazil: trends and challenges. Hum Resour Health. 2015;13(1):1-10. doi: 10.1186/ s12960-015-0095-2.

14. Almeida Júnior VP, Pedrosa PAE. Fundo de Financiamento Estudantil (Fies): vicissitudes e desafios. Radar. 2018;58(1)37-41 [access in 11 feb 2021]. Available from: http://repositorio.ipea.gov.br/bitstream/11058/8839/1/ Radar_n58_fundo.pdf.
15. Cabral Filho WR, Ribeiro VMB. A escolha precoce da especialidade pelo estudante de Medicina: um desafio para a educação médica. Rev Bras Educ Med. 2004;28(2):133-44. doi: 10.1590/1981-5271v28.2-018.

16. Lucchetti ALG, Lucchetti G. Medical job market in the state of São Paulo: investigation of job proposals in the site "Banco de Empregos Médicos". Rev Soc Bras Clín Méd. 2014;12(2):137-44 [access in 11 feb 2021]. Available from: http://files.bvs.br/upload/S/1679-1010/2014/v12n2/a4181.

17. Revista da Sociedade Brasileira de Clínica Médica e a valorização do clínico [editorial]. Rev Soc Bras Clín Méd. 2018;16(2):75-6 [access in 11 feb 2021]. Available from: http://www.sbcm.org.br/ojs3/index.php/rsbcm/article/ view/334/302.

18. Gouveia PAC, Ribeiro Neta MHC, Aschoff CAM, Gomes DP, Silva NAF, Cavalcanti HAF. Factors associated with burnout syndrome in medical residents of a university hospital. Rev Assoc Med Bras. 2017;63(6):504-11. doi: 10.1590/1806-9282.63.06.504.

19. Shanafelt TD, Bradley KA, Wipf JE, Back AL. Burnout and self-reported patient care in an internal medicine residency program. Ann Intern Med. 2002;136(5):358-67. doi: 10.7326/0003-4819-136-5-200203050-00008.

20. Rodrigues H, Cobucci R, Oliveira A, Cabral JV, Medeiros L, Gurgel K, et al. Burnout syndrome among medical residents: a systematic review and meta-analysis. PLoS ONE. 2018;13(11):e0206840. doi: 10.1371/journal. pone.0206840. 